\section{3. 核医学用フィルムの画質評価}

島根県立中央病院放射線科 新井 但: 福間時敏

最近CT, RI，超音波診断，マンモグラフ 等に適した 核医学用フィルムが各社から発売されているが CRT 画 像用に使用した結果，鮮鋭度，コントラストがすぐれて いた。 そこで一般撮影用フィルムと核医学用フィルムの $\mathrm{MTF}$ 比較を行ない数值的の差があるか否かを検討 した、鉛矩形波チャートを用いたコントラスト法にて実 施した結果，核医学用フィルムは一般撮影用フィルムに 比し MTF は高く鮮鋭度，コントラスト等の良さは実証 された．これらの核医学用フィルムが高画質な理由は微 粒子の片面乳剤で裏面にはアンチハレーション層を有し ているためベースカブリが小さいためで女ると思う。

\section{質問}

1. 使われたフィルムの具体的な商品名を教光て下さ W.

2. H-D curves を求める時, Time scale 法で行なわ れているが今後は他の方法を使用された方が良いと思い ます（相反則不軌の問題があるため).

\section{東田善治（山口大学）}

\section{答}

比較したフィルムは，フジ RX，コダック NMB，サ クラCタイプ以上です。

追加

特性曲線はタイムスケール法より強度スチール法でや るべきである。

\section{啠問}

新井 但（島根県立中央病院）

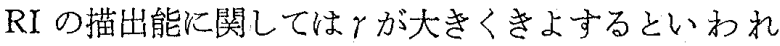
ているので，フィルムのケを执しえてほしい。

谷口金吾 (広島大学)

\section{答}

今回特に $\gamma$ 値の比較はして扔りません。

座長集約 $(28 \sim 33)$

鎌田三郎（鳥取県立厚生病䟚）

5 席の研究発表，それに対する質問等ですありました 上うに，医療被曝の問題は，我々日常の放射線業務の中 でぞうしてもつきまとう一番重要な問題であることは 云うまでも㐫りませ。

この被曝の管理は，我々放射線技師の分野で女ります。 又，核医学面での患者及び術者の被瀑問題，特に術者の 注射時の指，その他の部位への被曝に注意したい子ので あります，前の発表にもありましたように，被曝防護の 三原則，即ち，線源からの距離を大さ之とる，被嚗時間
を短かくする，遮蔽材料を用いて遮蔽する，この三原則 の遵守，又，技術的及び物理的因子等をよく検討し，今 日から根気よく被曝防護の啓蒙，教育実践を行ない，放 射線診断に和ける患者の防護と，放射線技師の敌かれた 立場を各自が十分認識し，正しく放射線を管理してゆこ らではありませんか……....

\section{4. 高感度撮影系の粒状性についての考察}

徳島大学医学部附属彰療放射線技師学校

八木浩史・藤田一彦・手川歓識

高感度增感紙あるいは高感度フィルムが試(使)用され るようになり被曝線量の軽減に役立っている。フィルム に達する線量の減少に伴い，量子ノイズを含め粒状性が 問題とな⿰ている．X線写真微細誩断では，視覚的粒状 性が問題となるが RMS 等の物理的表現とは必ずしも一 致しないのでそれに対して検討をしたので報告した．

(結果)

1）視覚的に問題となる粒状性は $0 \sim 2$ line $/ \mathrm{mm} の$ 範囲にあり，量子ノイズの領域と一致している。

2）高感度撮影系の粒状性沉いて，視覚と平行関係 そある表現としては $\mathrm{RMS}_{0-1}$ ，あるいは $\mathrm{RMS}_{0-2}$ を用い るのが適当である。

35. KODAK XV-2 FILM の治療分野への応用（第一 報 諸特性と照射野内平坦度測定への応用) 川崎医科大学附属病院中央放射線部 福田健二・友光達志・沼口健治 石井幸志・日地啓夫

KODAK XV-2 フィルムの ${ }^{60} \mathrm{Co} \gamma$ 線，6MVX 線汇関 寸る基礎的な諸特性について 検討し，一応用例として $6 \mathrm{MVX}$ 線の照射野内平坦度測定に用いた。

ファントム中で得られた線量一黒化度特性曲線は, ${ }^{60} \mathrm{Co}$ $\gamma$ 線〜120 rad， 6MVX 線〜160 rad の範囲では深さによ る変化はみられなかった．線束に平行に置いたフィルム の垂直フィルムに対する黑化度は， ${ }^{60} \mathrm{Co} \gamma$ 線約 $3 \%$, $6 \mathrm{MVX}$ 線約 $7 \%$ 低くなった。 ${ }^{60} \mathrm{Co} \gamma$ 線を基準とした $6 \mathrm{MVX}$ 線の同一線量に対する黒化度は，約 $9 \%$ 低くな った.

線量変換後の線量分布は，電離箱線量計による実測値 と一致し，自動的に線量変換を行なう装置を用いること により，平坦度を迅速に評価し得た。

36. 当院における過去10年間の $X$ 線検查の統計的考察 鳥取大学医学部附属病院 松下・博・長尾健治・西尾 剛 国岡孝志

〔結諭と考察】

患者数及びフィルム枚数共に年々增加しているが，患 